\title{
POLYGYNY AND FUNCTIONAL MONOGYNY IN LEPTOTHORAX ANTS (HYMENOPTERA: FORMICIDAE)
}

\author{
By J. HeINZE ${ }^{1}$ ANd A. BusChinger ${ }^{2}$
}

The number of queens present in colonies of social insects may affect several features of colony structure, such as the relationship between workers within the nest. The high degree of relatedness of nestmates, which is thought to be one of the fundamental traits in the evolution of altruistic behavior in Hymenoptera, can be sustained only if all the female brood is produced by one single queen (monogyny) that has been inseminated by only one male (monoandry).

During the last two decades numerous studies on queen number and colony structure of ants have shown, however, that in about 50 percent of all species colonies may contain several fully fertile queens (Buschinger, 1974a). Some species (e.g., Leptothorax acervorum or Myrmica ruginodis) are facultatively polygynous; in other species (e.g., Plagiolepis pygmaea or Formica exsecta) virtually all colonies are polygynous. Colonies of some highly polygynous species, such as Formica polyctena, may contain thousands of queens. Polygyny may arise by the cooperative foundation of new colonies by several inseminated young females (pleometrosis), by the fusion of colonies, or by the adoption of young, inseminated females into a colony.

In some taxonomic groups, polygyny appears to be associated with ecological factors, such as patchy distribution of habitats or high instability of nesting sites (Hölldobler and Wilson, 1977), and recently queen number has been interpreted as an ecologically responsive trait, explainable by a combination of kin selection and ecological elements (Nonacs, 1988). An obvious advantage of polygyny on the colony level is that the presence of multiple fertile

'Museum of Comparative Zoology, Harvard University, Cambridge, MA 02138, USA.

${ }^{2}$ Institut für Zoologie, TH Darmstadt, Schnittspahnstr. 3

D6100 Darmstadt, West Germany.

Manuscript received by the editor November 21, 1988. 
queens ensures the colony's continuation in the event of one or more queen deaths. In many monogynous species the death of the queen results in the dissolution of the colony (e.g., Oecophylla spec., Vanderplank, 1960). Polygyny, however, is not the only mechanism for queen replacement observed in ants. In some species, several dealate females may be present in a colony but only one lays eggs. Occasionally some of the extra females are sterile, uninseminated females that somehow missed the mating flight. Others are inseminated females, which do not lay eggs in the presence of the fully fertile queen. Tschinkel and Howard (1978) demonstrated the presence of these sterile, inseminated females in colonies of Solenopsis invicta by removing the single fertile queen. In 27 percent of the test colonies a previously sterile female began to lay fertilized eggs.

The presence of sterile, though inseminated females, in addition to a fertile queen has been termed "functional monogyny." Originally described by Pardi with the paper wasp, Polistes gallicus $(1940 ; 1946)$, functional monogyny appears to be very rare in ants. In addition to Solenopsis invicta, in which it occurs along with polygyny and monogyny, functional monogyny has so far been proven to exist only in some species of the well-studied ant tribe Leptothoracini: in Leptothorax gredleri (Buschinger, 1968a), Leptothorax sphagnicolus (Francoeur, 1986), and in some, if not all species of the xenobiotic genus Formicoxenus (Buschinger, 1979a; Buschinger and Winter, 1976; Buschinger et al., 1980; Francoeur et al., 1985).

With the exception of L. gredleri, which is fairly common in some populations in Bavaria (Buschinger, 1966), functionally monogynous leptothoracines are quite rare. Thus, more detailed studies on colony and population structure are difficult. During the past few years, however, we have collected numerous colonies of a new, functionally monogynous species of Leptothorax closely related to the palaearctic species L. muscorum. The taxon is to be described by A. Francoeur (Univ. of Quebec, Chicoutimi); here we again refer to it as Leptothorax spec. A (Heinze and Buschinger, 1987). This ant is common in suitable habitats throughout Quebec and the northern part of New England, and it is abundant especially on the rocky shore of St. Lawrence River near Tadoussac, Quebec. A most important trait of Leptothorax spec. A is that it has a genetically mediated queen-polymorphism, with primarily winged, gynomor- 
phic females and more or less workerlike, wingless queens, called intermorphs. Intermorphic queens most probably are of the genotype Ee and EE, whereas gynomorphs are always ee (Heinze and Buschinger, in prep.).

The small size of colonies and the ease of rearing them in the laboratory make Leptothorax spec. A an ideal ant for studies on colony and population structure and colony foundation behavior related to functional monogyny.

During our studies on $L$. spec. A we have gathered much data on the occurrence of polygyny in additional North American species of the subgenus Leptothorax s. str. M. R. Smith (= Mychothorax Ruzsky). In this paper we present field data and results of laboratory experiments concerning the colony structure of Leptothorax spec. A as well as field data on related species. In addition we summarize information on mono- and polygyny in some palaearctic Leptothorax.

\section{Methods ANd Material}

A total of 272 complete colonies of Leptothorax spec. A were collected in June 1983, 1985, and 1988 in Quebec (Tadoussac, La Baie, Laurentides). More than 250 additional colonies were gathered since 1979 in Quebec and adjacent areas of Ontario and Northern New England (Me.: Bar Harbor, Baxter State Park; N.H.: Mt. Monadnock). Some dozen colonies were kept alive for several breeding cycles under artificially shortened annual rhythms (Buschinger, 1974b), in the laboratory at TH Darmstadt, and for several months at room temperature in the MCZ labs in Cambridge.

Other Leptothorax, most living sympatrically with $L$. spec. A, were collected: $L$. retractus (Que.: Rouyn-Noranda; Alta.: Jasper, Banff), the presently undescribed $L$. spec. B (Que.: Tadoussac, La Baie, Laurentides; N.H.: Mt. Monadnock), L. spec. C (Alta.: Jasper, Banff, Kananaskis; B.C.: Yoho N.P.), and a Leptothorax species similar to $L$. spec. B (B.C.: Sutton Pass, Mt. Seymour, Manning Provincial Park).

Dissections of females and workers were carried out as described by Buschinger and Alloway (1978). Instead of killing the females by using acetic acid ethyl ether or ethanol, water with a drop of detergent was used in most cases, because it kills small ants faster than 
ethanol and does not affect the condition of the ovaries by dehydration. The ovaries were prepared by removing the subgenital plate with a pair of tweezers under a binocular microscope at $30 \times$ magnification. Ovariole development, contents of the receptacle and presence of corpora lutea were studied at $30 \times$ to $70 \times$ magnification. The condition of the ovaries was rated using the following classification, based on a system by Buschinger (1968a) and Buschinger and Alloway (1978).

A-females

a-females

Inseminated, fertile queens. Ovarioles are elongated, corpora lutea are present. In the reproductive season they contain numerous eggs with white yolk deposits.
b-females
b->A-females present, ovarioles are short. In gynomorphic fe- males, wing muscles replaced by fat body. Fat body usually yellow.
Young, inseminated, sterile females. No corpora lutea, ovarioles are short, sometimes they contain one or two eggs. In gynomorphic females, wing muscles not yet degenerated, fat body white.
Inseminated, sterile, but eggs in development. Ovarioles more or less elongated, no corpora lutea present.
c-females Not inseminated, sterile.
C-females Not inseminated, ovarioles elongated, containing eggs. Corpora lutea present. Old, inseminated females, sterile. No corpora lutea

Since the color of the fat body, which changes from white in younger females to yellowish in older ones, was not noted in all cases, we do not differentiate between freshly inseminated, sterile females (b) and those which have already been inseminated during a past season (a-females). Likewise, we do not differentiate between older uninseminated females and young uninseminated females, which have not yet started sexual behavior. As sexuals eclose in late June and July in most areas, inseminated females collected in June or July should all have mated already during the last years, and thus be a-females. Whereas all recently eclosed gynomorphic females are winged, it is not possible to tell this year's intermorphic females from older ones without judging the color of the fat body. Only colonies with several A-females were called polygynous; those with 
supernumerary a-females in addition to one single queen were called functionally monogynous.

Isoelectric focusing in ultrathin polyacrylamid gels was carried out to estimate relationships of nestmates within some colonies, and to secure conspecifity of allopatric colonies (Heinze and Buschinger, 1988).

\section{RESULTS}

\section{Leptothorax spec. A}

Fifty four of a total of 206 queenright colonies of Leptothorax spec. A collected in June 1983, 1985, and 1988 contained more than one and up to seven females (Table 1). In additional colonies collected in July 1987 and 1988, we counted up to 10 and more females, most of them inseminated. Because at the end of July this year's females have eclosed and may already have mated, it cannot be ruled out, however, that the higher number of females found at that time may be a transient phenomenon and that the young mated females will leave their mothers' nests before hibernation. It is quite certain that all females found in June colonies have hibernated in the nest, and we also found females in July and even August whose fat body color indicated that they had not eclosed recently.

All of the females and some of the workers in 30 colonies collected in June, and in an additional 59 colonies collected in July, were dissected. In all but four colonies only one female was found to be inseminated and fertile and, thus, a queen; the other females, though most were inseminated, did not show any corpora lutea and their ovarioles were only poorly developed (Table 2). In at least two of the four colonies with two A-females, workers engaged in heavy fighting and the queens were attacked. In these cases it is probable that neighboring nests were mixed by error during collection.

Both gynomorphic and intermorphic queens were accompanied by inseminated, sterile females, gynomorphic or intermorphic or both, but the percentage of June colonies with a gynomorphic queen and additional females was distinctly smaller (4.2 percent) than that of comparable colonies with intermorphic queens ( 28.9 percent). This difference is striking in each of the June collections and it is present in the July collection also. The majority of the supernumerary females (61 out of 80 ) were inseminated, but sterile. In three queenright colonies all the additional females were uninseminated. 


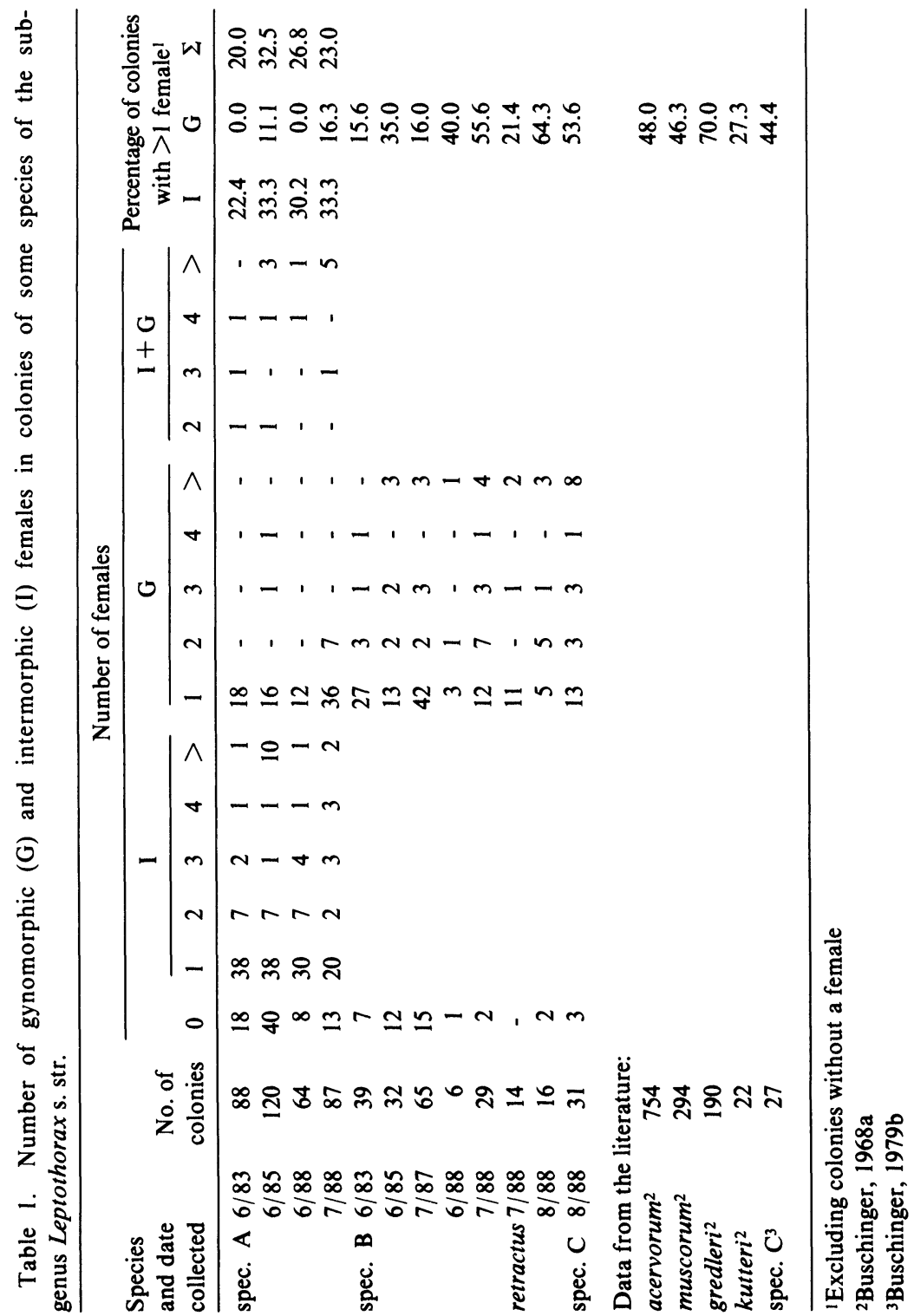


Five colonies in the June samples lacked fertile queens, but had one to three intermorphic $\mathrm{b}->\mathrm{A}$-females and additional $\mathrm{b}$-females. Of 36 colonies that had only a single female, 10 did not have a fertile queen but did have an intermorphic b- $>$ A-female, which in some cases was just ready to lay her first eggs. These presently queenless colonies usually were quite small and consisted of few (1 to 10) workers and some brood. We did not find any queenless colonies with gynomorphic $b->$ A females. All gynomorphic females that were the only female in the colony were found to be fully fertile. (In these evaluations the 12 colonies with both female morphs were not included. Females were dissected in only five of these colonies; in one case the queen was a gynomorph. Genetically mediated queen polymorphism in Leptothorax spec. A turned out to be a helpful tool in evaluating the relatedness of the different females in a colony. In one colony from Tadoussac, for example, the intermorphic queen produced only intermorphic female sexuals. One of the supernumerary females, however, was an inseminated gynomorphic female.)

C-females, not inseminated, but fertile females, which produce males, were found in two or three colonies in the field.

\section{Other Leptothorax}

As the data in Table 2 indicate, colonies of the closely related Leptothorax spec. B, of the Western species $C$ and of $L$. retractus frequently contained several females. Here dissections proved, however, that all three species regularly have truly polygynous societies. In colonies of spec. B, which were collected in June, usually all inseminated females were fertile. Colonies of $L$. retractus and $L$. spec. C were examined in August; here a certain percentage of the females may have been only recently inseminated and thus not yet fertile.

Colony founding in $L$. spec. A

Of the more than 500 colonies of Leptothorax spec. A collected by us since 1979 in North America, only two appeared to be incipient colonies, consisting of a single queen (one gynomorph and one intermorph) and brood. In two or three more cases the colony consisted of two females, one fertile, the other not, and brood. The occurrence of colonies without a fertile queen (see above) but with nearly fertile $b->A-f e m a l e s$, in June, suggests that colony foundation by budding or colony fission takes place. 
Table 2. Dissection results in colonies of Leptothorax s. str. with more than one female. AA, two or more fully fertile queens (polygyny); AAb, AAc, AAbc, two or more fully fertile queens, accompanied by one or several b- and/or c-females (polygyny); Ab, Ac, Abc, one fertile queen, accompanied by one or several $b$-females (functional monogyny) and/or c-females; b, c, bc, one or several b- and/or c-females without queen.

\begin{tabular}{|c|c|c|c|c|c|c|c|c|c|c|c|}
\hline & AA & $\mathrm{AAb}$ & AAbc & AAc & $\mathrm{Ab}$ & Abc & Ac & bc & b c c & Total & $\%$ AA \\
\hline spec. A June & $2^{\mathrm{a}}$ & $1^{\mathrm{a}}$ & - & - & 10 & 4 & 3 & 2 & $2-$ & 24 & 89 \\
\hline July & - & - & 1 & - & 3 & 8 & 4 & 2 & 23 & 21 & \\
\hline spec. B & 7 & 3 & - & 3 & 1 & 1 & 1 & 1 & - & 17 & 76.5 \\
\hline retractus & 2 & 1 & 1 & - & 1 & - & 1 & - & -- & 6 & 66.7 \\
\hline spec. C & 1 & - & - & 1 & - & 1 & - & 2 & 22 & 9 & 22.2 \\
\hline \multicolumn{8}{|c|}{ Data from the literature: } & \multicolumn{2}{|c|}{$\mathrm{bc}, \mathrm{b}, \mathrm{c}$} & & \\
\hline acervorum 1 & 40 & 2 & 3 & 12 & 3 & 2 & 54 & & 5 & 121 & 47.1 \\
\hline muscorum $^{2}$ & 3 & - & 5 & 1 & 17 & 15 & 9 & & 6 & 56 & 16.1 \\
\hline gredleri ${ }^{1}$ & - & - & - & - & & 26 & 20 & & - & 46 & - \\
\hline spec. $C^{3}$ & 2 & - & - & - & - & - & - & & - & 3 & 66.7 \\
\hline
\end{tabular}

${ }^{a}$ In two of these colonies fighting between workers was observed.

'Buschinger, 1968a

${ }^{2}$ Buschinger, 1967

${ }^{3}$ Buschinger, 1979b

In experiments carried out at the TH Darmstadt, $L$. spec. A females were given the chance to mate in arenas containing their maternal colony and in addition, empty nesting sites. Both winged gynomorphic and wingless intermorphic females perform a stationary sexual calling behavior similar to that of other leptothoracine ants, the so called "Locksterzeln" (Buschinger, 1968b). Whereas intermorphic females regularly started sexual display within a short distance of the nest entrance, winged females usually showed some flight activity before they began sexual calling.

Most intermorphic females returned into their mothers' colonies within a few hours after mating, and none of 41 intermorphic females, compared to 13 of 43 gynomorphic females, hibernated outside their mothers' nests. Under laboratory conditions no young, inseminated female, intermorphic or gynomorphic, successfully founded a colony on its own and raised brood during the first following summer. The majority of inseminated females, which were kept separate from workers, were able to survive two, three, or more hibernations. Both intermorphic and gynomorphic females left their 
nests to search for food and fed their own larvae. Only one single gynomorphic queen, however, managed to rear her own workers in the second summer after mating; in most cases the brood eventually died.

In the laboratory, supernumerary females have been found to survive for several artificial breeding cycles in the presence of the old queen. Aggression of the workers toward their young inseminated sisters was observed only in colonies with gynomorphs. Here 13 of 19 females, which had been put back into their mothers' nest and were not given the chance to escape, were killed by workers within a few weeks after copulation, their antennae and legs having been cut off. The dissection showed that in most of these females the development of eggs had already started and the ovarioles were elongated. Four other inseminated females were tolerated in this colony for at least one hibernation. Foreign inseminated females were never tolerated by a colony, regardless of the morpha.

In several cases, fission of colonies with two or more inseminated females occurred after hibernation. Old nesting sites were abandoned and workers moved brood and adults into two or even three different new nesting sites. In comparable situations, colonies with only one single female usually gathered in one nesting site after a few days. Spontaneous fission of colonies with several females, however, led in three instances to two independent societies each, which did not exchange brood or workers. One colony fused again after two breeding cycles, but only after one of the two queens had died.

Queen replacement was observed in five colonies, where a hitherto sterile female became fertile after the old queen had died. In two colonies, this event was pursued in electrophoretical enzyme analysis. The esterase locus \#7 is variable in Leptothorax spec. A and in other related species; its at least four different allozymes can be separated by isoelectric focusing (Heinze and Buschinger, 1988). Queen replacement was reflected in a change of the esterase genotype of worker pupae. A colony from Baie Ste. Catherine, Que., which before had workers with the esterase genotypes BC and BD, now reared diploid brood with the genotype AC, too, thus decreasing the relatedness of workers within the colony. In an additional colony from Rivière Romaine, Que., queen replacement led to a change in the morpha of young females. Whereas the old queen had 
reared both morphs, the replacement queen only produced intermorphic females.

Of the 222 colonies of Leptothorax spec. B two contained a single queen and brood only, and a third one consisted of two fertile females and brood. Three more colonies might have been incipient, too, but here one worker had already eclosed. However, 7 of 14 colonies of a dark brown ant morphologically similar to $L$. spec. B, which were collected near Vancouver, B.C., in August 1988, were found without workers.

\section{Discussion}

The ant tribe Leptothoracini consists of several hundred species of small- to medium-sized ants, which form colonies of several dozen to few hundreds of workers. It exhibits a rich variety of different social structures and colony foundation behaviors. Apart from social parasites, which may be inquilines, degenerate slavemakers, active dulotes, and xenobiotic guest ants, the non parasitic species have been found to be obligatorily monogynous, functionally monogynous, or facultatively polygynous (Buschinger, 1974a).

We here report on functional monogyny and polygyny in some species of the subgenus Leptothorax s.str. M. R. Smith (= Mychothorax Ruzsky) from North America. Between 20 and 30 percent of the colonies of $L$. retractus, $L$. spec. B, and $L$. spec. C are truly polygynous. The fertility of several inseminated females has been proven by dissection; in a number of cases, egg-laying has been directly observed. In Leptothorax spec. A, about one-fourth of all colonies with intermorphic queens contained additional, inseminated females, again mostly intermorphs, which in almost all cases have been found to be sterile. An occasional polygyny in Leptothorax spec. A cannot be ruled out but it seems to be very rare.

There are two important differences between functional monogyny in polistine wasps and in Leptothoracini. In Polistes gallicus, Pardi $(1940 ; 1946)$ had observed that when two females cooperate in colony foundation, the more aggressive one becomes queen, and the subordinate one becomes worker. In colonies with several females, however, ovary size and fertility correspond to the female's rank in a dominance hierarchy. Several females may lay eggs, though in differing degrees, and functional monogyny is sometimes guaranteed only by differential egg consumption by the dominant $\alpha$-female 
(Gervet, 1964). In most cases the coexistence of several inseminated females in one nest is transient, and it resembles the regulation of queen number in obligatorily monogynous ants after colony foundation by pleometrosis (Buschinger, 1974a). In leptothoracine ants, on the other hand, functional monogyny is total and may be a lasting phenomenon. Only the queen has fully developed ovaries; those of the supernumerary females are always undeveloped. The presence of $\mathbf{b}->\mathrm{A}-\mathrm{females}$ with elongated ovarioles in colonies of Leptothorax spec. A is restricted to a short period of time and leads to colony fission or, as was observed in the lab, to aggressive behavior toward the young female and finally to her death. Whether dominance hierarchies exist in colonies with several supernumerary females, as in Polistes, is not yet known.

Our observations suggest that, comparable to primary and secondary polygyny, functional monogyny in Leptothoracini may arise in two ways. Intermorphic females, and perhaps gynomorphic females also, are easily accepted in their mothers' colonies after mating, and they may stay there for several breeding cycles. The other possibility, a pleometrosis-like colony foundation with several inseminated young females, one of which becomes fertile, has been observed in the field only two or three times. The find of a gynomorphic supernumerary female in a colony with an intermorphic queen which produced only intermorphic female sexuals does not necessarily indicate that foreign females are adopted; the gynomorph might have accompanied a sister during pleometrosis or budding.

According to our results, all species belonging to Leptothorax s. str., including $L$. acervorum, $L$. muscorum, and $L$. gredleri from Eurasia, may have colonies with several inseminated females, as is the fact too in some of the parasitic species, e.g. L. kutteri (Buschinger, 1968a), and in the genus Formicoxenus, which seems closely related to Leptothorax s. str. In the subgenus Myrafant and its satellite genera Epimyrma, Myrmoxenus, Chalepoxenus, and Protomognathus, however, most species are obligatorily monogynous. In Myrafant and its parasites, facultative polygyny occurs only occasionally as in the North American species $L$. longispinosus, $L$. ambiguus, and L. curvispinosus (Alloway et al., 1982), or in Epimyrma algeriana (Buschinger et al., in prep.). In studies on polygyny in different populations of $L$. longispinosus, a latitudinal cline in the frequency of multiple-queened nests has been suggested; 
southern populations seem more likely to be monogynous than northern populations (Herbers, 1986a). Several other factors influence the pattern of polygyny, such as the scarcity of available nest sites (Herbers, 1986b). Neighboring populations, therefore, may differ in the frequency of polygynous colonies, as was shown, e.g., in L. curvispinosus. In one population 75 percent of the colonies contained several females, but in a population $7 \mathrm{~km}$ away only 38.8 percent were polygynous (Stuart, 1987).

The facultatively polygynous and functionally monogynous species of the subgenus Leptothorax s. str. usually live in boreal or alpine coniferous habitats. Of all North American ants, $L$. "muscorum", comprising several species like Leptothorax spec. A, B, and $\mathrm{C}$, is the species best able to survive in extreme arctic and alpine conditions (Brown, 1955). With colonies found in north Alaska (Nielsen, 1987) and near the tree line in Nouveau Québec (Francoeur, 1983), both $L$. "muscorum" and $L$. acervorum are among the few species of Formicidae that are found so far north.

Species of the subgenus Myrafant, on the other hand, are abundant in areas with mild conditions in winter, such as the Mediterranean. Of the numerous species of this subgenus, only five reach Scandinavia, including Denmark (Collingwood, 1979), and among those are the facultatively polygynous $L$. tuberum and $L$. interruptus (Buschinger, 1968a; 1974a) and L. nylanderi, of which polygynous colonies have occasionally been found in the field (Chauvin, 1947; Plateaux, 1970). Populations of Myrafant in alpine areas, such as $L$. tuberum in the Alps, tend to be facultatively polygynous as well (Buschinger, 1968a), and facultatively polygynous $L$. longispinosus and L. ambiguus are the only Myrafant to be found in Quebec or Ontario (Creighton, 1950). Some populations of $L$. rugatulus found at higher elevations in the Rocky Mountains apparently are facultatively polygynous, too (S. Cover, pers. comm.).

As Bolton (1986) has pointed out, polygyny and colony fission in certain African and Levantine species of the Monomorium salomonis group might be an adaptation to hot and dry summers, which eventually has led to the evolution of apterous or workerlike queens.

Colony structure and intermorphic females in the ant tribe Leptothoracini might be an analogous adaptation to extremely cold climates. In areas with long and severe winters a young female perhaps will have more success in raising offspring if she hibernates in a 
conspecific colony (whether becoming fertile there or not) and founding her own colony in one of the following springs either solitarily or by budding or colony fission. Whereas independent colony foundation by young Myrafant queens has frequently been observed, females of Leptothorax s. str. have only occasionally been found to hibernate solitarily. Buschinger (1968a) collected 13 incipient colonies, consisting of queen and brood only, in a total of 754 nests of $L$. acervorum, and 2 in 319 colonies of $L$. muscorum. Incipient colonies are rare in $L$. spec. A and B, too, far too rare to explain the abundance of mature colonies. Observations made in August 1988 on Mt. Seymour near Vancouver, however, indicate that there is a certain percentage of gynomorphic Leptothorax females which do not immediately return to conspecific colonies after mating. A similar behavior was observed in gynomorphic females of Leptothorax spec. A. in laboratory experiments. The rarity of incipient colonies in spring might perhaps be due to a low survival rate of solitarily hibernating females or to a return of females into conspecific colonies in late fall.

In $L$. spec. A queen polymorphism, together with differences in mating behavior, may have led to alternative dispersal strategies. Intermorphs mate in the immediate neighborhood of their colonies and are easily accepted back after mating, hence the high percentage of nests with supernumerary intermorphs in the field. Gynomorphic females, on the other hand, show some flight activity before starting sexual calling behavior, and might not be able to find their way home. In constrast to $L$. acervorum, where allozyme data suggest that foreign females perhaps are tolerated in other colonies (Douwes et al., 1987), in Leptothorax spec. A workers show aggression toward foreign young inseminated females, and eventually kill them. After hibernation in conspecific nests, females of Leptothorax s. str. might found colonies either solitarily, as was assumed for L. muscorum (Buschinger and Winter, 1978), or by budding.

In polygynous species, colony fission might increase the kinship in the daughter colonies compared to that in the mother colony by giving the workers the chance to arrange in different matrilines (Crozier, 1981), and indeed the segregation of workers into sororities has been observed in the honey bee (Getz et al., 1982). In functionally monogynous species, however, the overall level relatedness might decrease by budding, similar to the relations in colony fission 
in army ants. The evolution of the colony fission mode of reproduction, a phenomenon common in army ants (e.g., Franks and Hölldobler, 1987), was analyzed by Macevicz (1979) both from the kin selectionist and parental manipulationist point of view. Thus, in some cases workers might not suffer a loss in their own inclusive fitness by accompanying their sisters and rearing nieces and nephews instead of brothers and sisters. Workers, e.g., might select the queen with the higher life expectancy, instead of staying with their mother. In honeybees, the old queen leaves the nest and incurs the risks involved with founding a new colony, but almost no details are known about the circumstances of budding in Leptothorax ants. Allozyme data (unpubl. results) did not shown any evidence for inbreeding in Leptothorax spec. A, which would increase the relatedness between workers and their nieces.

Additional field studies are under way to screen annual changes in colony and population structure of Leptothorax spec. A and to find out more about the success of colony foundation behaviors in different habitats.

\section{SUMMARY}

Data are given on the colony structure of some North American ant species belonging to the myrmicine subgenus Leptothorax s. str. The species studied by now are either functionally monogynous (i.e., sterile, inseminated females may accompany the queen, Leptothorax spec. A) or facultatively polygynous (i.e., several fully fertile, inseminated queens may contribute to the offspring). Incipient colonies of these species are rare in the field; young females probably return into conspecific colonies after mating in summer and found their own colonies by budding in spring. The behavior of young intermorphic and gynomorphic females after mating was studied in the functionally monogynous Leptothorax spec. A. In this species, queen replacement and colony fission were observed, too.

\section{ACKNOWLEDGMENTS}

Parts of these studies were made possible by a grant from the NATO science council thru DAAD to J. H. We thank S. Cover, 
MCZ, Cambridge, for helpful comments on the manuscript, and $\mathbf{J}$. Dougherty, Newton, for improving the English.

\section{ReFERENCES CITED}

Alloway, T. M., Buschinger, A., Talbot M., Stuart R., and Thomas, C.

1982. Polygyny and polydomy in three north American species of the genus Leptothorax Mayr (Hymenoptera: Formicidae). Psyche 89: 249-274.

Bolton, B.

1986. Apterous females and shift of dispersal strategy in the Monomorium salomonis-group (Hymenoptera: Formicidae). J. Nat. Hist. 20: 267-272.

Brown, W. L.

1955. The ant Leptothorax muscorum in North America. Ent. News 66: 43-50. BUSCHINGER, A.

1966. Leptothorax (Mychothorax) muscorum Nylander und L. (M.) gredleri Mayr zwei gute Arten. Ins. Soc. 13: 165-172.

1967. Verbreitung und Auswirkungen von Monogynie und Polygynie bei Arten der Gattung Leptothorax Mayr (Hymenoptera, Formicidae). Inaugural-Diss., Universität Würzburg.

1968a. Mono- und Polygynie bei Arten der Gattung Leptothorax Mayr (Hymenoptera, Formicidae). Ins. Soc. 15: 217-226.

1968b. "Locksterzeln" begattungsbereiter ergatoider Weibchen von Harpagoxenus sublaevis Nyl. (Hymenoptera: Formicidae). Experientia 24: 297.

1974a. Mono- und Polygynie in Insektensozietäten. in: Schmidt, G. H. (ed.) Sozialpolymorphismus bei Insekten. Wiss. Verlagsges. $\mathrm{mbH}$, Stuttgart. pp. 862-896.

1974b. Experimente und Beobachtungen zur Gründung und Entwicklung neuer Sozietäten der sklavenhaltenden Ameise Harpagoxenus sublaevis (Nyl.). Ins. Soc. 21: 381-406.

1979a. Functional monogyny in the American guest ant, Formicoxenus hirticornis (Emery) (= Leptothorax hirticornis) (Hym., Form.). Ins. Soc. 26: 61-68.

1979b. Doronomyrmex pocahontas n. sp., a parasitic ant from Alberta, Canada (Hym., Formicidae). Ins. Soc. 26: 216-222.

Buschinger, A. And Alloway, T.

1978. Caste polymorphism in Harpagoxenus canadensis M. R. Smith (Hym., Formicidae). Ins. Soc. 25: 339-350.

Buschinger, A., Francoeur, A. and Fischer, K.

1980. Functional monogyny, sexual behavior, and karyotype of the guest ant, Leptothorax provancheri Emery (Hymenoptera; Formicidae). Psyche 87: 1-12.

Buschinger, A., Jessen, K., and Cagniant, H.

(in prep.) The life history of Epimyrma algeriana, a slave-making ant with facultative polygyny (Hymenoptera, Formicidae). 
BUSCHINGER, A. AND Winter, U.

1976. Funktionelle Monogynie bei der Gastameise Formicoxenus nitidulus (Nyl.) (Hym., Form.) Ins. Soc. 23: 549-558.

1978. Echte Arbeiterinnen, fertile Arbeiterinnen und sterile Wirtsweibchen in Völkern der dulotischen Ameise Harpagoxenus sublaevis (Nyl.) (Hym., Form.). Ins. Soc. 25: 63-78.

Chauvin, R.

1947. Sur l'élevage de Leptothorax nylanderi (Hymenoptère Formicide) et sur l'essaimage in vitro. Bull. Soc. Zool. Fr. 72: 151-157.

Collingwood, C. A.

1979. The Formicidae (Hymenoptera) of Fennoscandia and Denmark. Fauna Entomol. Scand., 174 pp.

Creighton, W. S.

1950. The ants of North America. Bull. Mus. Comp. Zool. [Mass.] 104, 585 pp.

Crozier, R. H.

1981. Genetic aspects of ant evolution. In: Atchley, W. R. and Woodruff, D. (eds.) Evolution and speciation. Essays in honor of M. J. D. White. Cambridge Univ. Press, pp. 356-370.

Douwes, P., Sivusaari, L., Niklasson, M., and Stille B.

1987. Relatedness among queens in polygynous nests of the ant Leptothorax acervorum. Genetica 75: 23-29.

Francoevr, A.

1983. The ant-fauna near the tree-line in Northern Quebec (Formicidae: Hymenoptera). Nordicana 47: 177-180.

1986. Deux nouvelles fourmis nearctiques: Leptothorax retractus et Leptothorax sphagnicolus (Formicidae, Hymenoptera). Can. Ent. 118: 1151-1164.

Francoeur, A., Loiselle, R., And Buschinger, A.

1985. Biosystèmatique de la tribu Leptothoracini (Formicidae, Hymenoptera). 1. Le genre Formico-xenus dans la région holarctique. Naturaliste can. (Rev. Ecol. Syst.). 112: 343-403.

Franks, N. R. ANd Hölldóbler, B.

1987. Sexual competition during colony reproduction in army ants. Biol. Journ. Linn. Soc. 30: 229-243.

Gervet, J.

1964. Le comportement d'oophagie differentielle chez Polistes gallicus L. (Hymen., Vesp.). Ins. Soc. 11: 343-382.

Getz, W. M., Brứckner, D., und Parisian, T. R.

1986. Kin structure and the swarming behavior of the honey bee, Apis mellifera. Behav. Ecol. Sociobiol. 10: 265-270.

Heinze, J AND Buschinger, A.

1987. Queen polymorphism in a non-parasitic Leptothorax species (Hymenoptera, Formicidae). Ins. Soc. 34: 28-43.

1988. Electrophoretic variability of esterases in the ant-tribe, Leptothoracini. Biochem. Syst. Ecol. 16: 217-221. 
(in prep.) Queen-polymorphism in Leptothorax spec. A: its genetical and ecological background (Hymenoptera Formicidae).

Herbers, J. M.

1986a. Ecological genetics of queen number in Leptothorax longispinosus Mayr (Hymenoptera: Formicidae) Entomol. Gener. 11: 119-123.

1986b. Nest site limitation and facultative polygyny in the ant, $L$. longispinosus. Behav. Ecol. Sociobiol. 19: 115-122.

HölLDOBLER, B. AND WILSON, E. O.

1977. The number of queens: an important trait in ant evolution. Naturwissenschaften 64: 8-15.

MaCevicz, S.

1979. Some consequences of Fischer's sex ratio principle for social Hymenoptera that reproduce by colony fission. Am. Nat. 113: 363-371.

NiELSEN, M. G.

1987. The ant fauna (Hymenoptera: Formicidae) in northern and interior Alaska. Ent. News 98: 74-81.

Nonacs, $\mathrm{P}$.

1988. Queen number in colonies of social hymenoptera as a kin-selected adaptation. Evolution 42: 566-580.

PARDI, L.

1940. Ricerche sui Polistini. 1. Poliginia vera ed apparente in Polistes gallicus L. Atti Soc. Toscana Sci. Nat. 49: 3-9.

1946. Ricerche sui Polistini. VII. La "dominazione" e il ciclo ovarico annuale in Polistes gallicus (L.) Boll. Ist. dei Entomol. Univ. Studi Bologna 15: 25-84.

Plateaux, L.

1970. Sur le polymorphisme social de la fourmi Leptothorax nylanderi (Forster). I. Morphologie et biologie comparées des castes. Ins. Soc. 12: 373-478.

STUART, R. J.

1987. Transient nestmate recognition cues contribute to a multicolonial population structure in the ant, Leptothorax curvispinosus. Behav. Ecol. Sociobiol. 21: 229-235.

TSChinkel, W. R. AND Howard, D. F.

1978. Queen replacement in orphaned colonies of the fire ant, Solenopsis invicta. Behav. Ecol. Sociobiol. 3: 297-310.

VANDERPLANK, F. L.

1960. The bionomics and ecology of the red tree ant, Oecophylla spec., and its relationship to the coconut bug, Pseudotheraptus wayi. J. Anim. Ecol. 29: 15-33. 

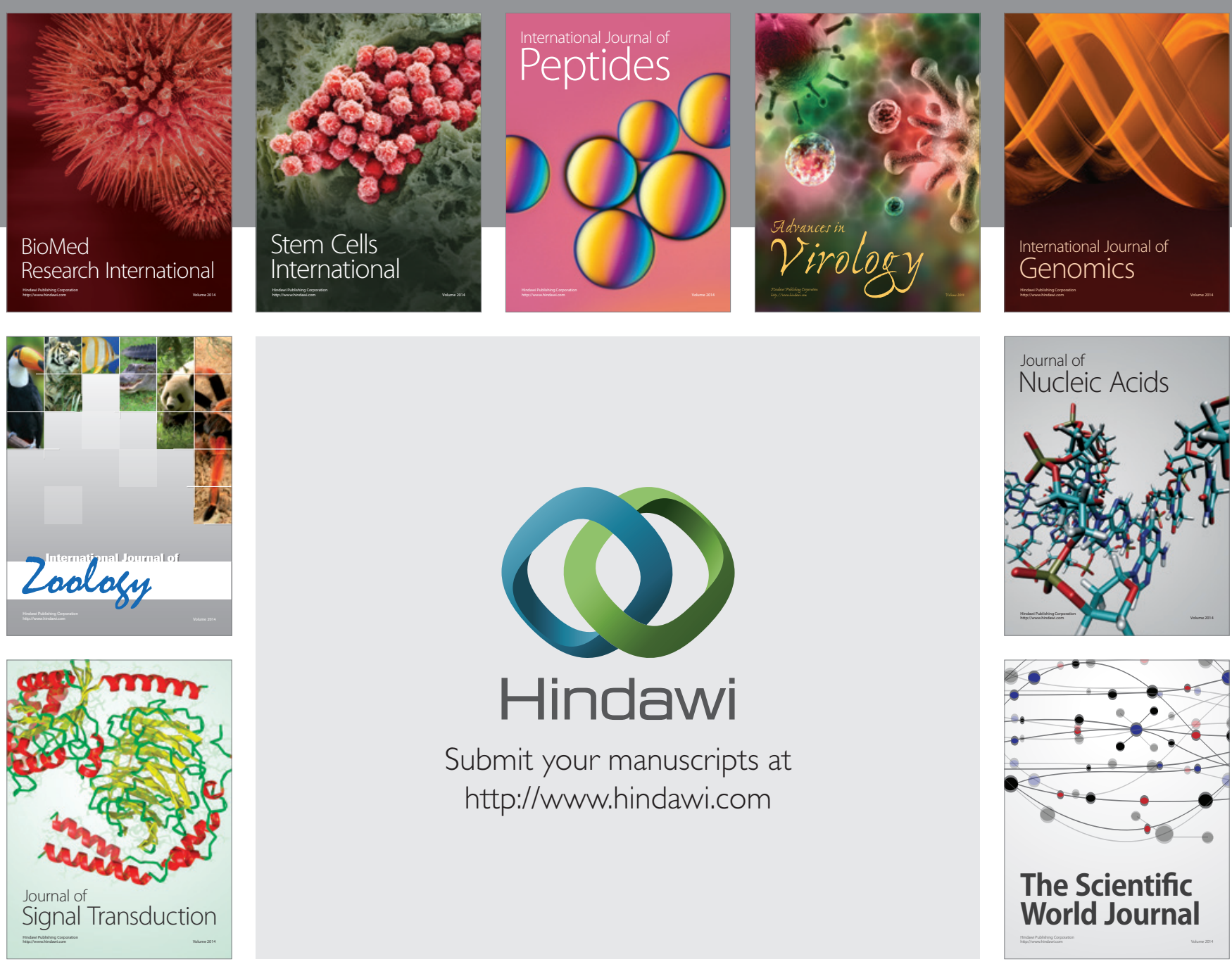

Submit your manuscripts at

http://www.hindawi.com
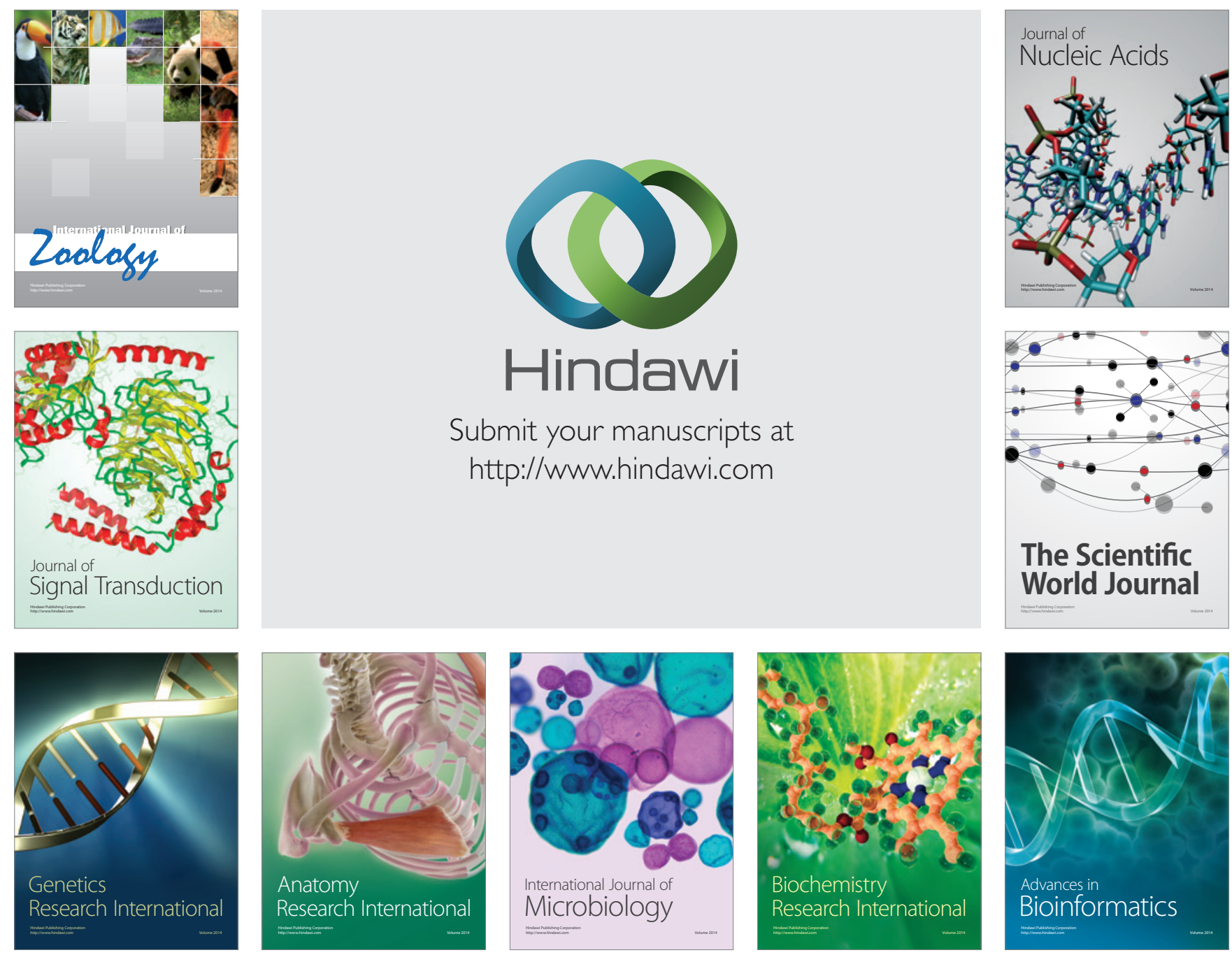

The Scientific World Journal
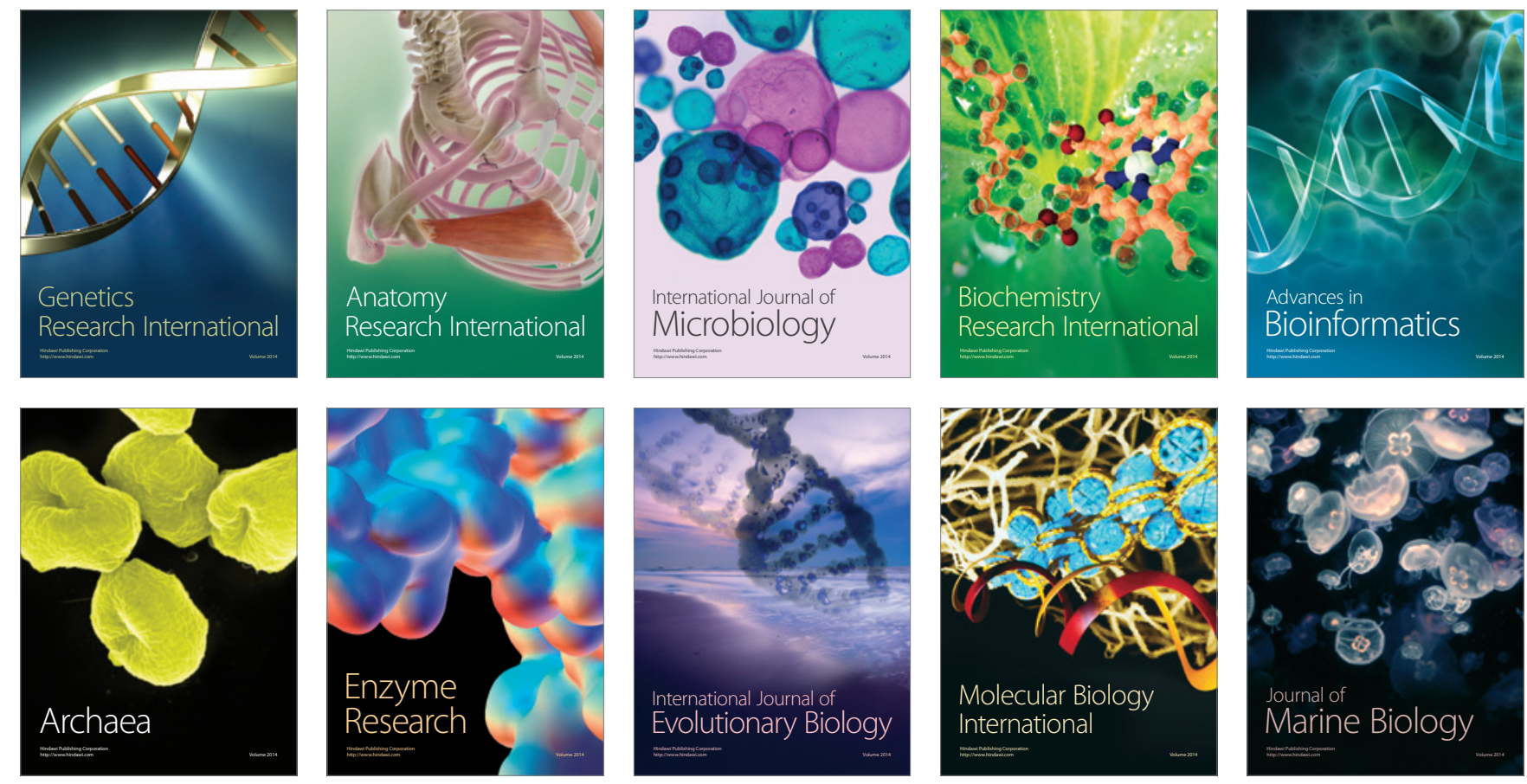